\title{
AN INTERNATIONAL COMPARISON OF SCIENCE EDUCATION
}

$\mathrm{M}^{\mathrm{r}}$ R. J. L. LEWIS, senior science master at Malvern College, has examined methods of teaching science in the United States, Western Germany and the U.S.S.R. In the first of two articles, he compares the relative merits of those methods with such as are used in English schools (Esso Magazine, Winter, 1961/1962).

Education in the U.S.S.R. is compulsory during the ages of 7-18 and the same course is followed by every child for the first eight years of his or her timo at school. This basic course starts with the Russian language, Russian literature and mathematies. At the age of nine a foreign language is introduced, then history, geography, Leninism-Marxism theory and biology. A little later physics is begun and, a year later, chemistry. In other words, the Russian educational curriculum is fairly broad and the same standard, equivalent to the General Certificate of Education in England, is attained by every child. There is no streaming and no examination at 11-plus.

Mr. Lewis claims that pupils in Russian schools believe passionately in work. It is even a privilege, not a punishment, to be kept in after school. Education is the one way to open up the future for the Russian boy or girl, the one way to enable them to avoid spending their lives in factory or in field. That is an inducement. There is also the passion for the acquisition of knowledge which is too frequently lacking in English schools. Mr. Lewis includes in his picture of Russian life street corners abounding in bookstalls filled with books on physics, mathematics and astronomy. Throughout the day trestle tables are erected and crowds collect around their array of books. In the Moscow Metro and in the buses people are reading books on physics, mathematics and astronomy. Education in physies really matters. He rightly or wrongly questions whether it really does matter in Britain.

Western Germany has long had its tradition of good physics teaching. Physics is respected as a subject of major importance for the second half of the twentieth century and plays its part in the education of every boy and girl in the German gymnasiums. Could this be claimed for English grammar schools, where the educational system is still fundamentally classical in tradition? Latin, from the age of eight to sixteen, for several periods a week is said to provide "a broad liberal education". Two periods a week of science at the age of eleven have been called "gross specialization". It would seem that the English people are too complacent when others are believing passionately in the slogans "Work, work and work" and "Physies is life".

Other dangers, Lewis believes, also beset us. Teachers often tend to teach what they themselves were taught. This has doubtless contributed to the surprisingly fow changes in the content of the school science courses despite advances which have been made. Physics has remained in its watertight compartments-heat, light and sound; magnetism and electricity. There seems to be an unawareness that there is any modern physics of relevance to the schoolboy or girl. There are, of course, still those who say that all modern physics should be left to the universities, but they forget how small is the proportion of those at school who will study physies at the university. In the second half of the twentieth century every boy and girl leaving school ought to have some knowledge of radioactivity and $\mathrm{X}$-rays. The new syllabuses recently proposed by the Science Masters' Association have included some of this: however, the tragedy is that it has taken sixty years to begin to get topics included despite the fact that the U.S.S.R. and Germany have taught modern physics in schools for many years. Mr. Lewis rightly poses two questions which lead from such developments. What of equipment in English schools? What of laboratories? On the whole there is no great problem in England with regard to laboratories; however, with equipment, the situation is not satisfactory.

Throughout Western Germany there is an immense wealth of large-scale demonstration equipment for the teaching of science. University lectures are always accompanied by demonstrations which naturally stim. ulate and maintain the interest of the student. How often in England does the student in the university or the pupil at school have to be content with talk and chalk and occasionally the lantern slide. How easy it would be to capture the imagination of the boy with some of the excellent equipment available in Germany.

Good demonstration equipment is expensive. But in Germany, after the Second World War, it was decided that modern physics should be taught in German schools. To make this possible the Federal Ministry of Atomic Energy prepared a plan to make available 18 million D.-marks (just less than $£ 2,000,000$ ) and the funds were distributed at the rat $\theta$ of 12,000 D.-marks or more than $£ 1,000$ per school. This was given equally to State schools, municipal schools and to private schools, on condition that it was to be used on equipment for developing the teaching of modern physies in the last three years in the gymnasium. This special grant transformed the teaching, and it accounts for the expensive demonstration equipment used. Mr. Lewis warns that, despite the efforts now being made, England, and Britain as a whole, is in great danger of lagging behind.

Mr. Lewis now comes to the question of the teachers and whether or not, in England, the best use is made of the material available.

The English science teacher, in general, is given complete freedom to present his subject as he wishes. This will lead to the best results if the teacher is good and if he has sufficient time to think out his presentation. The trouble is that there are never enough good teachers and these seldom have sufficient time. The problem is also very real in the U.S.S.R., where it is conceivable that there will never be enough teachers, and consequently they have set about providing the 
material to enable indifforent teachers to teach well. The Russian science teachers are teaching as much science in less time than their British counterparts due to the fact that the teacher is given more guidance and far more aids to teaching. If the means of teaching science subjects more efficiently were available, the English schoolmaster might achieve much more in fewer periode and the shortage of teachers might not be so acute.

In the U.S.S.R. there are research institutes for devising school experiments and designing apparatus. In England this is usually done by the busy schoolmaster in any spare moments he may have, and, as Mr. Lewis states, "We cannot afford to continue in this amateurish way". Not only is the Russian teacher provided with a complete set of demonstration apparatus for his course, but he is well supplied with films on the subjects being taught. All this does much to help the teacher: it does not impede the good teacher from developing his own ideas, but it does enable the indifferent teacher to achieve a minimum standard, to teach with a minimum of efficiency.

Another serious problem is that, in England, the assumption is made that a young man merely has to take his science degree and can then teach for the next thirty years without ever returning for further instruction, refreshment or guidance. In the United States last year more than 17,000 high school science teachers attended summer institutes. In England, less than a hundred attended Ministry of Education courses for grammar school science teachers. The American summer institutes last from six to eight weeks; the courses in Britain usually last less than at fortnight.

Mr. Lewis has dealt with some of the problems confronting science education in England to-day. They are serious indeed if England, and Britain as a whole, is not to lag far behind what is being done in other countries.

\section{EXPERIMENT IN EXAMINING FIRST-YEAR CHEMISTRY STUDENTS}

IN teaching chemistry, as with other scientific disciplines, there is a number of objectives. More often than not these objectives remain implicit in the minds of the lecturers. If they are made more explicit, it is usually in rather inexact and personal terms.

A general taxonomy of educational objectives has been developed by B. S. Bloom and others at the University of Chicago which contains six major classes: (1) knowledge; (2) comprehension; (3) application; (4) analysis; (5) synthesis; (6) evaluation. These six elasses are subdivided, defined and illustrated by example. Several members of the University of Melbourne Chemistry Department explored the adequacy of this taxonomy for chemistry applying it to old examination papers, and the following simplification of Bloom's definitions of classes was produced:

(1) Knowledge, involves simply the recall of material directly taught.

(2) Comprehension, involves understanding of the material taught, to the extent that it is recognized when presented in any form.

(3) Application, involves the use of such material in a new situation.

(4) Analysis, where the breakdown into detail involves both the facts and their relation in a new situation.

(5) Synthesis, where previously presented material is assembled to create something new.

(6) Evaluation, involves judgments using undefined criteria about values in a chemical situation.

These categories, so defined, were found to cover most questions on a number of examination papers, although one question would often involve the components of several classes.

With this experience as a basis, a first-year paper was set covering all six classes. The questions were so designed that the percentage marks obtained for oach class were easily extracted from the total, in the course of normal marking procedure. The examination was taken by 150 students, and as all the questions set were compulsory, the performances were directly comparable. The results have been described by P. J. Fensham of the University of Melbourne (Vestes, 4, No. 4; December 1961).

The customary way of assessing performance was in terms of the total percentage for the whole paper. This method gave the following results: honours (1st, 2nd and 3rd combined), 25; pass, 93; fail, 32. These three grades were then analysed by performance in the various classifications, particular attention being directed to the difference between honours and pass, and between pass and fail. It was clear that the major factor distinguishing between honours and pass was better performance of the honours group in classes 1,2 and 3. This group averaged 78 per cent in the first three classes and 70 per cent for the last three, whereas pass students averaged 54 per cent in both sets of classes. However, twelve students who were graded as pass students achieved at least 66 per cent in classes 4,5 and 6 , whereas eight of the students who were awarded honours all scored less than this for those same classes.

A reasonable hypothesis for this type of examination might be that honours should be awarded to those who perform better at the more complex objectives of the last three classes, assuming a certain competence in the first three. If so, the experiment suggests that the traditional grading by overall percentages involves serious errors in distinguishing between honours and pass students. (A single paper of this type, however, appears unsuitable to make the distinction, for 70 per cent of it had to be devoted to questions in the first three classes, if the material of the course had to be reasonably covered. This meant there was not enough room left in the paper for a sufficient number of questions of classes 4,5 and 6 .)

So far as the distinction between pass and fail is concerned, it might be reasonable to award a pass for a minimum level of performance in the first three classes, ignoring performance in the other classes 